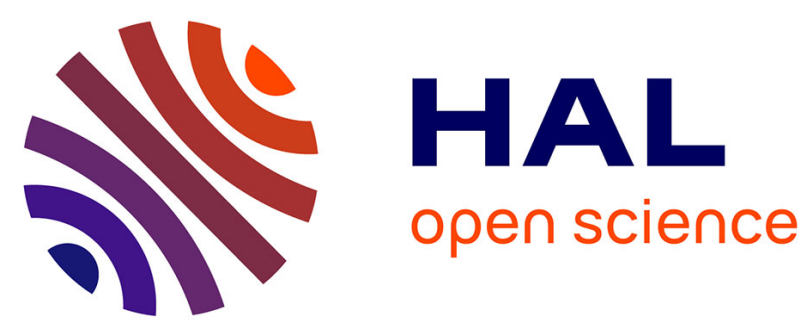

\title{
Design of a lattice-matched III-V-N/Si photovoltaic tandem cell monolithically integrated on silicon substrate
}

Alain Rolland, Laurent Pedesseau, Jacky Even, Samy Almosni, Cédric Robert Robert, Charles Cornet, Jean-Marc Jancu, Jamal Benhlal, Olivier Durand, Alain Le Corre, et al.

\section{To cite this version:}

Alain Rolland, Laurent Pedesseau, Jacky Even, Samy Almosni, Cédric Robert Robert, et al.. Design of a lattice-matched III-V-N/Si photovoltaic tandem cell monolithically integrated on silicon substrate. 13th International Conference on Numerical Simulation of Optoelectronic Devices (NUSOD 2013), Aug 2013, Vancouver, Canada. pp.1397-1403, 10.1007/s11082-014-9909-z . hal-00951949

\section{HAL Id: hal-00951949 https://hal.science/hal-00951949}

Submitted on 10 Mar 2014

HAL is a multi-disciplinary open access archive for the deposit and dissemination of scientific research documents, whether they are published or not. The documents may come from teaching and research institutions in France or abroad, or from public or private research centers.
L'archive ouverte pluridisciplinaire HAL, est destinée au dépôt et à la diffusion de documents scientifiques de niveau recherche, publiés ou non, émanant des établissements d'enseignement et de recherche français ou étrangers, des laboratoires publics ou privés. 


\title{
Design of a lattice-matched III-V-N/Si photovoltaic tandem cell monolithically integrated on silicon substrate
}

\author{
ALAIN ROLLAND ${ }^{1, *}$, LAURENT PEDESSEAU ${ }^{1}$, JACKY EVEN $^{1}$, SAMY ALMOSNI ${ }^{1}$, CEDRIC ROBERT ${ }^{1}$, CHARLES \\ CORNET $^{1}$, JEAN MARC JANCU ${ }^{1}$, JAMAL BENHLAL ${ }^{1}$, OLIVIER DURAND ${ }^{1}$, ALAIN LE CORRE ${ }^{1}$, PIERRE RALE ${ }^{2}$, \\ LAURENT LOMBEZ ${ }^{2}$, JEAN-FRANCOIS GUILLEMOLES ${ }^{2}$, ERIC TEA ${ }^{2}$, AND SANA LARIBI ${ }^{2}$.
}

${ }^{1}$ Université Européenne de Bretagne, INSA Rennes, CNRS, UMR 6082 FOTON-OHM, 20 avenue des Buttes de Coësmes 35708

Rennes, France

${ }^{2}$ Institut de Recherche et Développement sur l'Energie Photovoltaïque (IRDEP), UMR 7174 - CNRS-EDF-ENSCP, EDF R\&D, 6 quai Watier, 78401 Chatou Cedex, France

(*author for correspondence: E-mail: alain.rolland@univ-rennes1.fr)

\begin{abstract}
In this paper, we present a comprehensive study of high efficiencies tandem solar cells monolithically grown on a silicon substrate using GaAsPN absorber layer. InGaAs(N) quantum dots and GaAsPN quantum wells have been grown recently on GaP/Si susbstrate for applications related to light emission. For photovoltaic applications, we consider the GaAsPN diluted nitride alloy as the top junction material due to both its perfect lattice matching with $\mathrm{Si}$ and ideal bandgap energy for current generation in association with the Si bottom cell. Numerical simulation of the top cell is performed. The effect of layer thicknesses and doping on the cell efficiency are evidenced. In these structures a tunnel junction (TJ) is needed to interconnect both the top and bottom sub-cells. We compare the simulated performances of different TJ structures and show that the $\mathrm{GaP}(\mathrm{n}+) / \mathrm{Si}(\mathrm{p}+) \mathrm{TJ}$ is promising to improve performances of the current-voltage characteristic.
\end{abstract}

Keywords: Tandem solar cells, tunnel junctions, numerical simulation, Photonics on silicon

\section{Introduction}

Nowadays emphasizes is put on environmental protection and energy needs make solar energy become a major energy source in the future. In this context, there is a strong effort underway to lower the cost of the photovoltaic kilowatt-peak toward new material systems. However the concept of a silicon-based single junction solar cell does not lead to an optimal use of the whole solar spectrum. Its high energy part is lost by carrier thermalisation. To overcome this limitation, the concept of multi-junction solar cell has been proposed and efficiency over $40 \%$ were reported for GaAs based cells (Geisz et al. 2008; Ming-Han and Yuh-Renn 2012; Baudrit et al. 2008; Baudrit et al. 2010; Friedman et al. 2010; Green et al. 2010; Green et al. 2013).

Recent progress in III-V-N alloys monolithic growth on silicon substrate (Robert et al. 2012; Robert et al. 2011) led our research team to propose these promising materials for multi-junction solar cells (Almosni et al. 2013; Ming-Han and Yuh-Renn 2012; Aho et al. 2010). In this paper, we propose a GaAsPN diluted nitride alloy as the top junction material of a $\mathrm{Si}$ based tandem solar cell. Its perfect lattice matching with $\mathrm{Si}$ and ideal bandgap energy of $1.7 \mathrm{eV}$, are both appealing for optimal current generation with a $1.1 \mathrm{eV}$ bandgap Si bottom cell. In this work we present numerical simulation results for the top PIN GaP/GaAs $\mathrm{P}_{1-x} \mathrm{~N} / \mathrm{GaP}$ junction. Modeling is performed using the ATLAS device simulator (Silvaco). Optimized layer thicknesses and doping for the top PIN GaP/GaAs $\mathrm{P}_{1-\mathrm{x}} \mathrm{N} / \mathrm{GaP}$ junction in terms of efficiency are determined. A key factor to achieve efficient tandem solar cells is the tunnel junction (TJ) between top and bottom sub-cells (Baudrit et al. 2008; Baudrit et al. 2010). We compare the theoretical performances of various TJ structures and show that the $\mathrm{GaP}(\mathrm{n}+) / \mathrm{Si}(\mathrm{p}+)$ exhibits the best current-voltage characteristic. 


\section{GaAsPN absorbing layer}

In order to successfully design a multi-junction cell in the pseudomorphic approach, issues of low defects density at the interface (lattice matching) and current matching between the different cells have to be adressed. Efficiency as high as $44 \%$ has been recently reported using InGaAsN diluted nitride on GaAs substrate, but the limitation of this approach is the coast of the GaAs substrate. To overcome this limitation we propose to use the $\mathrm{GaAs}_{0.1} \mathrm{P}_{0.87} \mathrm{~N}_{0.03}$ diluted nitride system which is expected to have a perfect lattice matching with $\mathrm{Si}$ or GaP and a pseudo-direct bandgap energy of about $1.7 \mathrm{eV}$ (Nguyen Thanh et al. 2008).

As already shown in previous work (Almosni et al. 2013), lattice matching is obtained between GaAsPN grown by Molecular Beam Epitaxy and the $\mathrm{GaP}$ (or $\mathrm{Si}$ ) substrate. The band gap of the GaAsP alloy is indirect for a small As content (less than 10\%) (Harris et al. 2008; Robert et al. 2012). The direct band gap character is enhanced in dilute $\operatorname{GaAsP}(\mathrm{N})$ nitrogen alloys, as confirmed experimentally by time-resolved photoluminescence (Almosni et al. 2013). Fig. 1 shows the measured variation of the refractive index (real and imaginary part) of a $1 \mu \mathrm{m}$ thick GaAsPN layer at a $70^{\circ}$ angle of incidence and the corresponding absorption, which vanishes below $1.7 \mathrm{eV}$. The experimental data have been fitted using a dispersion models (Forouhi et al. 1986; Adachi 1989) for the GaAsPN layer and its native oxide respectively.

\section{Modeling}

Modeling is performed using the ATLAS device simulator by Silvaco which allows to numerically solve Poisson's equation coupled with continuity equations for both electrons and holes under steady state conditions. An important key feature of the tandem solar cell is the TJ interconnecting both top and bottom sub-cells. In this work, the performances of various tunnel junction diodes have been compared. We use the TJ model implemented in the ATLAS simulator which has been widely validated in the literature for Silicon (Lavery 2008) and for III-V semiconductors (Baudrit et al 2008; Baudrit et al 2010; Allen 2010)..

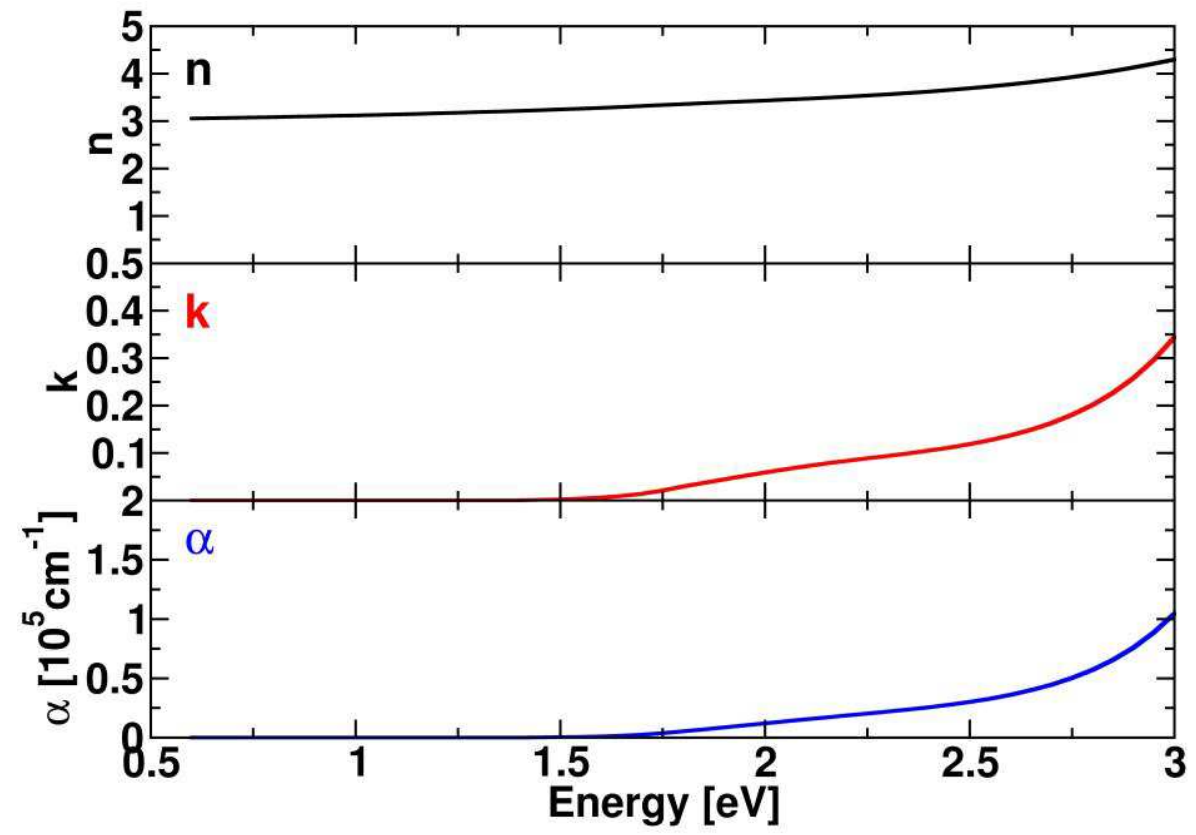

Fig. 1. Real and imaginary part of the GaAsPN refractive index and related absorption coefficient

\section{Tunnel junction}


Fig. 2(a) shows the schematic structure of the tandem solar cell. Four tunnel junctions configurations have been studied in this work: $\mathrm{Si}(\mathrm{n}+) / \mathrm{Si}(\mathrm{p}+), \mathrm{GaP}(\mathrm{n}+) / \mathrm{GaP}(\mathrm{p}+), \mathrm{GaP}(\mathrm{n}+) / \mathrm{Si}(\mathrm{p}+)$ and $\mathrm{GaP}(\mathrm{p}+) / \mathrm{Si}(\mathrm{n}+)$. The layers thicknesses for the simulation were $20 \mathrm{~nm}$. Actually, such thin heavily doped Si layer leads obviously to negligible light absorption.

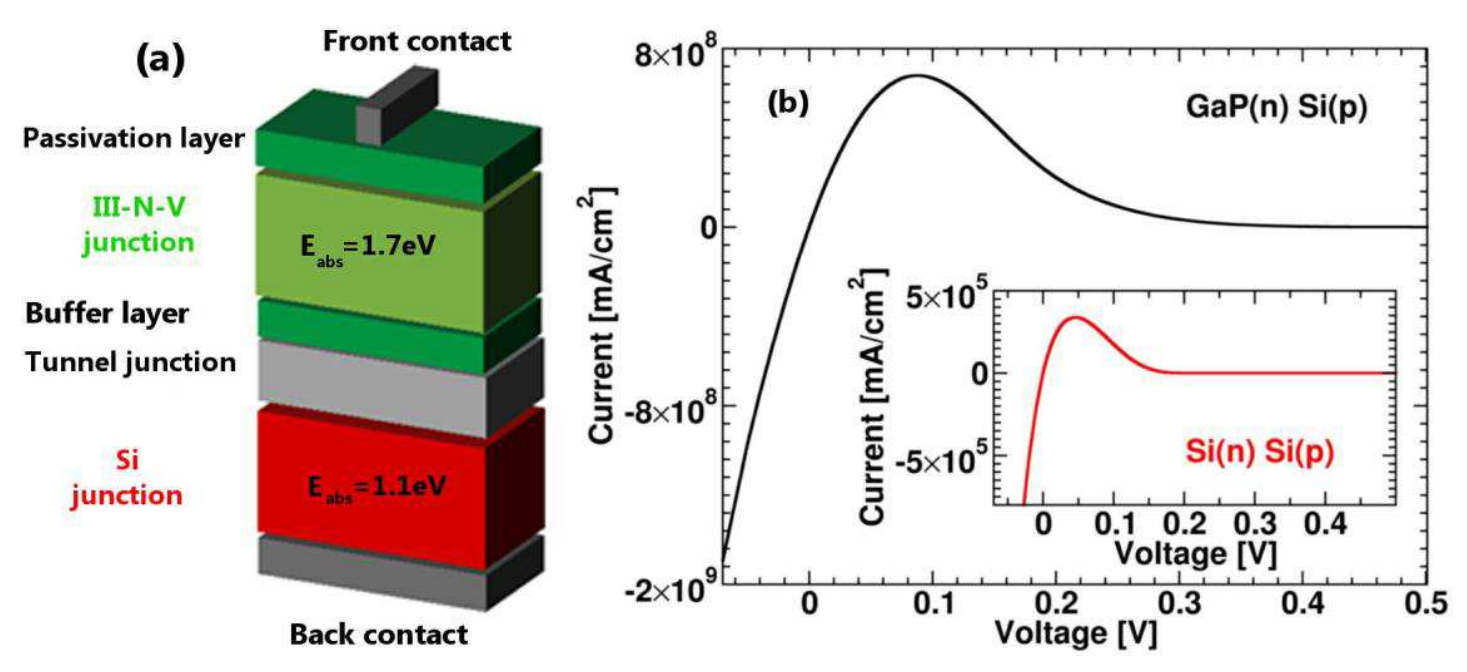

Fig. 2. (a) Schematic of the GaAsPN/Si tandem cell and (b) Simulated current-voltage characteristic of a GaP-n+/Si-p+ and Si$\mathrm{n}+/ \mathrm{Si}-\mathrm{p}+$ tunnel junctions at uniform doping of $10^{20} \mathrm{~cm}^{-3}$

We used the defaults material parameters provided by the Atlas simulator for the $\mathrm{Si}(\mathrm{GaP})$ gap energy $1.08 \mathrm{eV}(2.26 \mathrm{eV})$ and electron affinity $4.17 \mathrm{eV}(4.4 \mathrm{eV})$. For a large uniform doping level $\left(10^{20} \mathrm{~cm}^{-3}\right)$, the $\mathrm{GaP}(\mathrm{n}+) / \mathrm{Si}(\mathrm{p}+)$ TJ is much more efficient than the $\mathrm{Si}(\mathrm{n}+) / \mathrm{Si}(\mathrm{p}+) \mathrm{TJ}$ as shown in Fig. 2(b) and Table I because the tunneling barrier thickness is lower for the former case (see Fig. 3).

\begin{tabular}{|c|c|c|c|c|}
\hline Parameters & $\mathrm{GaP}(\mathrm{n}+) / \mathrm{Si}(\mathrm{p}+)$ & $\mathrm{GaP}(\mathrm{p}+) / \mathrm{Si}(\mathrm{n}+)$ & $\mathrm{GaP}(\mathrm{n}+) / \mathrm{GaP}(\mathrm{p}+)$ & $\mathrm{Si}(\mathrm{n}+) / \mathrm{Si}(\mathrm{p}+)$ \\
\hline $\mathrm{Vp}(\mathrm{mV})$ & 92 & 35 & 70 & 45 \\
\hline $\mathrm{Ip}\left(\mathrm{mA} / \mathrm{cm}^{2}\right)$ & $8.4 \times 10^{8}$ & $\sim 10^{-4}$ & $\sim 10^{-3}$ & $3.4 \times 10^{5}$ \\
\hline $\mathrm{L}_{\mathrm{B}}(\mathrm{nm})$ & 3.3 & 6.9 & 5.9 & 4.4 \\
\hline
\end{tabular}

TABLE I: THE VOLTAGE Vp, PEAK CURRENT DENSITIES Ip, AND THE BARRIER THICKNESSES L ${ }_{\mathrm{B}}$ OF THE FOUR TJ AT UNIFORM DOPING OF $10^{20} \mathrm{~cm}^{-3}$ 

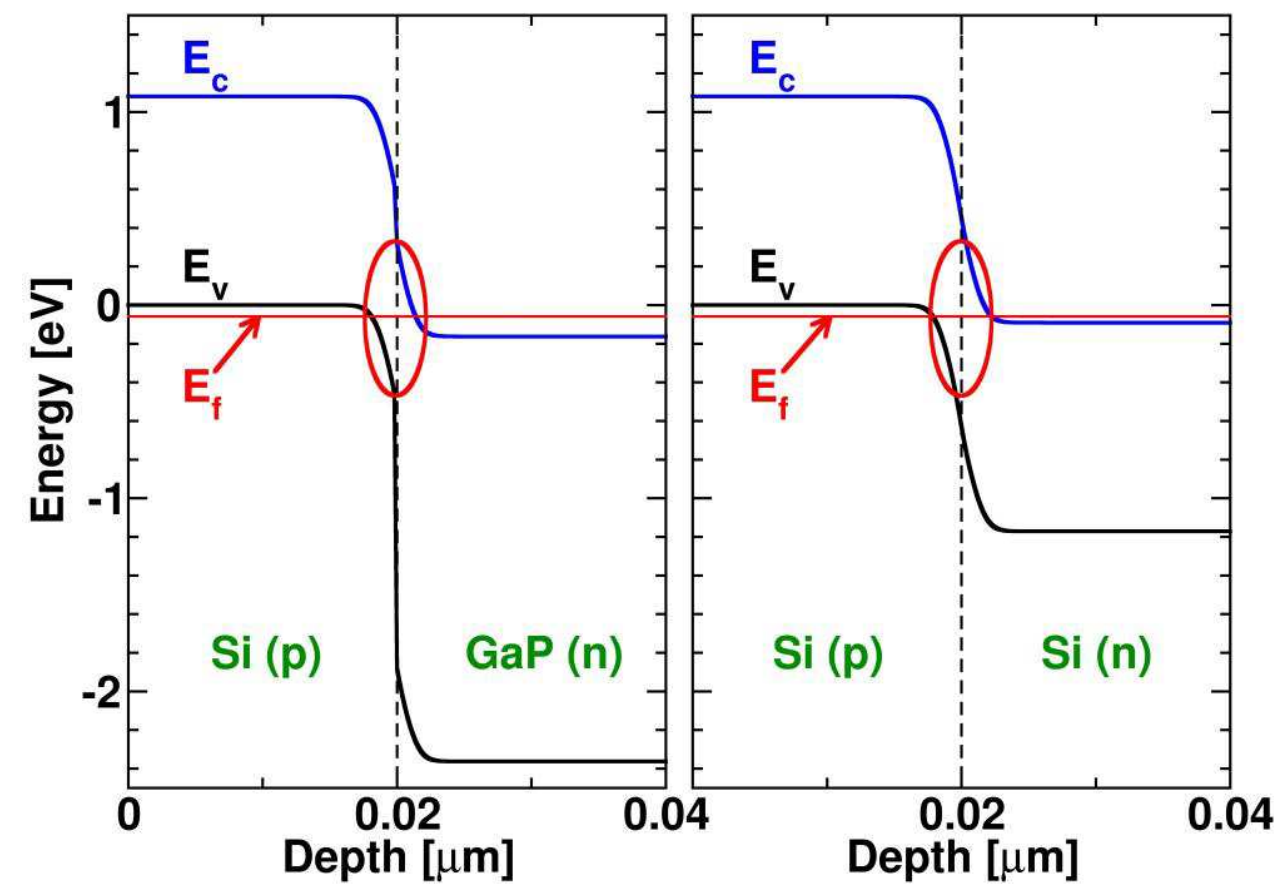

Fig. 3. Simulated Band diagram of a GaP-n+/Si-p+ and Si-n+/Si-p+ tunnel junctions at uniform doping of $10^{20} \mathrm{~cm}^{-3}$ at thermal equilibrium. The origin of the energy scale is taken at the top of the valence band of $\operatorname{Si}(\mathrm{p})$. In this figure: $\mathrm{E}_{\mathrm{c}}, \mathrm{E}_{\mathrm{v}}$ and $\mathrm{E}_{\mathrm{f}}$ are the bottom of the conduction band, the top of the valence band and the Fermi level of the homo/heterostructure.

\section{Top cell structure and material parameters}

Table II shows the basic structure of the GaAsPN top cell as well as the doping levels of the various layers, and Table III reports the main material parameters used for the simulation.

\begin{tabular}{|ccc|}
\hline GaP & $\mathrm{P}++5 \times 10^{18} \mathrm{~cm}^{-3}$ & $50 \mathrm{~nm}$ \\
\hline GaP & $\mathrm{P}+5 \times 10^{18} \mathrm{~cm}^{-3} \quad 200 \mathrm{~nm}$ \\
\hline & & \\
\hline $\mathbf{G a A s}_{0.1} \mathbf{P}_{0.9} \mathbf{N}$ & intrinsic & $1000 \mathrm{~nm}$ \\
\hline & & \\
\hline GaP & $\mathrm{n}+1 \times 10^{18} \mathrm{~cm}^{-3}$ & $30 \mathrm{~nm}$ \\
\hline
\end{tabular}

TABLE II: LAYER THICKNESSES AND DOPING

\begin{tabular}{|c|c|c|}
\hline Parameters & GaP & GaAsPN \\
\hline $\mathrm{E}_{\mathrm{g}}(\mathrm{eV})$ & 2.2 & 1.7 \\
\hline$\mu_{\mathrm{n}}\left(\mathrm{cm}^{2} \mathrm{~V}^{-1} \mathrm{~s}^{-1}\right)$ & 150 & 1000 \\
\hline$\mu_{\mathrm{p}}\left(\mathrm{cm}^{2} \mathrm{~V}^{-1} \mathrm{~s}^{-1}\right)$ & 80 & 80 \\
\hline$\tau_{\mathrm{n}}(\mathrm{s})$ & $10^{-8}$ & $10^{-10}$ \\
\hline$\tau_{\mathrm{p}}(\mathrm{s})$ & $10^{-8}$ & $10^{-10}$ \\
\hline$\chi(\mathrm{eV})$ & 3.8 & 4.3 \\
\hline
\end{tabular}


Due to the lack of experimental data for the GaAsPN system, carrier mobility and lifetime values reported in table III were chosen according to earlier published results obtained for the GaInAsN material (Geisz et al. 2002; Fahy et al. 2004; Kashner et al. 2001). In these works, electron mobility ranging from 100 to 2000 $\mathrm{cm}^{2} \mathrm{~V}^{-1} \mathrm{~s}^{-1}$ and carriers lifetime (at room temperature) ranging from 0.1 to $1 \mathrm{~ns}$ were reported.

\section{Results}

Fig. 4 shows the theoretical effect of the GaAsPN absorber layer thickness on the cell's current-voltage characteristic under AM1.5 solar flux. It can be seen that when increasing the GaAsPN layer thickness from $500 \mathrm{~nm}$ to $3000 \mathrm{~nm}$, the open circuit voltage decreases because of the voltage drop due to the parasitic resistance effect, while the short circuit current increases because the density of generated carriers increases. Therefore, an optimum cell efficiency of $9.42 \%$ can be obtained for a GaAsPN layer thickness of about $1 \mu \mathrm{m}$. This last result can be inferred more accurately from Fig. 5(a) which shows the theoretical variation of the cell efficiency as a function of the wavelength for various GaAsPN layer thicknesses. The simulation was based on experimental values of the absorption coefficient of the GaAsPN material and shows an increase of the cell efficiency around $600 \mathrm{~nm}$ with the GaAsPN thickness due to the absorption of GaAsPN material.

First samples have been grown in our laboratory. Fig. 5(b) shows that the measured efficiency variations follow the same trend as the theoretical ones. However, the maximum cell efficiency due to the photo-carriers created in the GaAsPN intrinsic layer of the structure remains quite low. This poor performance could be attributed to low carrier mobility and/or short carrier lifetime. Indeed, in this structure, the intrinsic absorbing layer plays the role of the depletion region which explains that the current increases with the width of the GaAsPN layer. This is especially true for thicknesses which correspond to carrier transit times smaller than the carrier life times (Fig. 4). In fact, Nitrogen-induced defects have been observed in GaAsPN alloys grown on GaP (Jandieri et al 2013) and improvement is still needed to reach a better quality of the materials through growth condition optimization or sample annealing to reduce the influence of these remaining defects on both carrier mobility and lifetime in the GaAsPN layer.

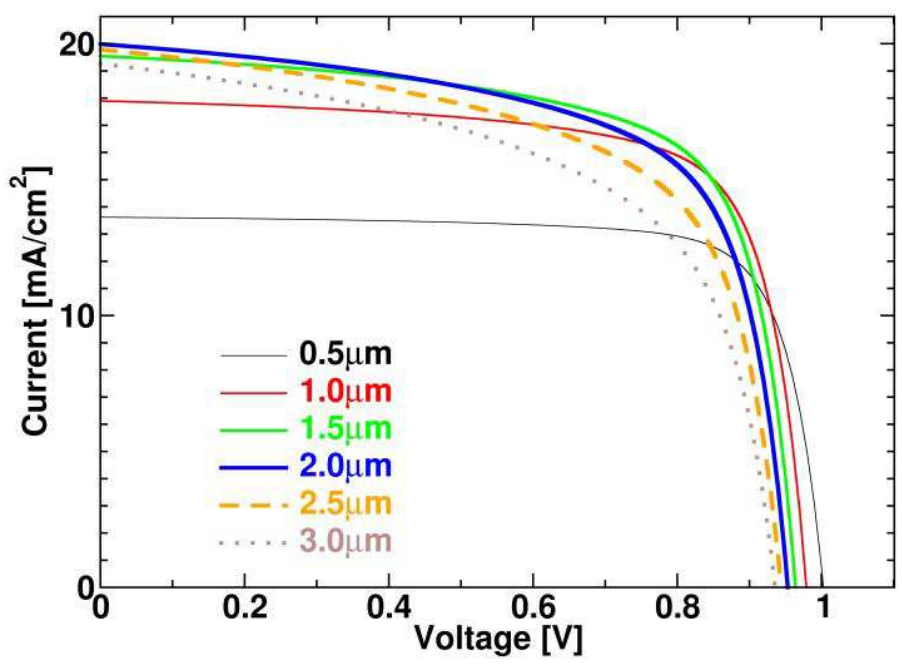

Fig. 4. Current voltage characteristic of the GaP/GaAsPN/GaP cell for GaAsPN layer thicknesses ranging from $0.5 \mu \mathrm{m}$ to $3 \mu \mathrm{m}$. 

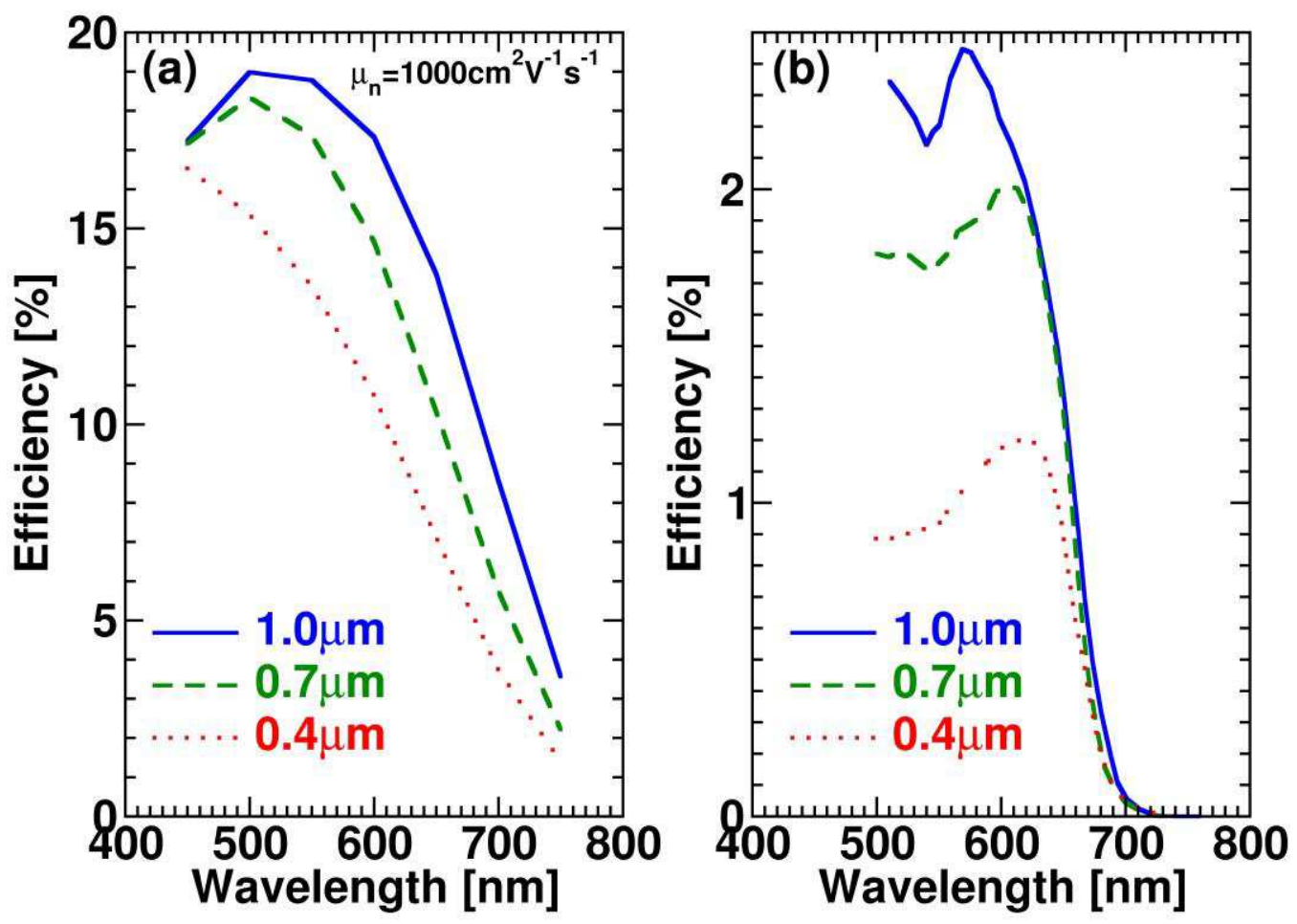

Fig. 5. (a)Simulated efficiency for GaP/GaAsPN/GaP top cell as a function of the wavelength for GaAsPN layer thicknesses ranging from $0.4 \mu \mathrm{m}$ to $1 \mu \mathrm{m}$ for $\mu_{\mathrm{n}}=1000 \mathrm{~cm}^{2} \mathrm{~V}^{-1} \mathrm{~s}^{-1}$. (b) Measured efficiency for GaP/GaAsPN/GaP top cells as a function of the wavelength for GaAsPN layer thicknesses ranging from $0.4 \mu \mathrm{m}$ to $1 \mu \mathrm{m}$.

\section{Conclusion}

In summary, we have shown that GaAsPN diluted nitride is a good candidate to play the role of the absorbing layer of the top cell because of its good lattice matching with silicon substrate and its bandgap energy of 1.7 $\mathrm{eV}$. We found that the $\mathrm{GaP}(\mathrm{n}+) / \mathrm{Si}(\mathrm{p}+)$ heterostructure is the best tunnel junction configuration to interconnect both top and bottom cells. The correct trend is simulated for the variation of the tandem cell efficiency as a function of the GaAsPN layer thickness. Nevertheless, simulations indicate that there is still room for improvement of the maximum cell efficiency. Material optimization is still needed to improve carrier mobilities and lifetimes. Available material parameters for GaAsPN alloys are scarce. We hope that the present work will stimulate further experimental studies on these materials.

\section{Acknowledgment}

The work was supported by the MENHIRS ANR project (2011-PRGE-007-01). The authors would like to thank Pr. R. Lefort for fruitful discussions on the GaAsPN ellipsometric model.

\section{References}

Geisz, J. F., Friedman, D. J., Ward, J. S., Duda, A., Olavarria, W. J., Moriarty, T. E., Kiehl, J. T., Romero, M. J., Norman, A. G. and Jones, K. M. Appl. Phys. Lett. 93, 123505, 2008

Ming-Han, H. and Yuh-Renn, W. Photovoltaic Specialist Conference (PVSC), 38th IEEE, 002052-002055, 2012

Baudrit, M., and Algora, C.. Photovoltaic Specialist Conference (PVSC), 1-5, 2008

Baudrit, M. and Algora, C. IEEE transactions on electron devices, 57, 2564, 2010

Robert, C., Perrin, M., Cornet, C., Even, J. and Jancu, J. M.. Appl. Phys. Lett .100, 111901, 2012

Robert, C., Bondi, A., Nguyen Thanh, T., Even, J., Cornet, C., Durand, O., Burin, J.P., Jancu, J.M., Guo, W., Letoublon, A., Folliot, H., Boyer-Richard, S., Perrin, M., Chevalier, N., Dehaese, O., Tavernier, K., Loualiche, S. and Le Corre, A.. Appl. Phys. 
Lett. 98, 251110, 2011

Almosni, S., Robert, C., Nguyen Thanh, T., Cornet, C., Létoublon, A., Quinci, T., Levallois, C., Perrin, M., Kuyyalil, J., Pedesseau, L., Balocchi, A., Barate, P., Even, J., Jancu, J. M., Bertru, N., Marie, X., Durand, O. and Le Corre, A.. J. Appl. Phys. 113, 123509, 2013

Aho, A., Tukiainen, A., Polojärvi, V., Korpijärvi, V., Gubanov, A., Salmi, J., Guina, M. and Laukkanen, P.. 26th European photovoltaic solar energy conferences and exhibition, pp. 58-61, 2010.

Silvaco “ATLAS user's manual”, (http://silvaco.com)

Nguyen Thanh, T., Robert, C., Guo, W., Létoublon, A., Cornet, C., Elias, G., Ponchet, A., Rohel, T., Bertru, N., Balocchi, A., Durand, O., Micha, J.S., Perrin, M., Loualiche, S., Marie, X. and Le Corre, A. J. Appl. Phys. 112, 053521, 2012

Harris, C., Lindsay, A. and O’Reilly, E. P.. J. Phys.: Condens. Matter 20, 295211, 2008

Geisz, J. F. and Friedman, D. J. Semicond. Sci. Technol. 17, 769-777, 2002

Fahy, S. Lindsay, A. and O’Reilly, E.P. IEEE Proc.-Optoelectron. Vol. 151, No. 5, 352-356, 2004

Jandieri, K., Kunert, B., Liebich, S., Zimprich, M., Volz, K., Stolz, W., Gebhard, F., Baranovskii, S. D., Koukourakis, N., Gerhardt, N. C. and Hoffmann, M. R., Phys. Rev. B 87, 035303, 2013

Kashner, A., Luttgert, T., Born, H., Hoffmann, A., Egorov, A. Y. and Riechert, H. Appl Phys. Lett. 78, 1391, 2001

Green, M. A., Emery, K., Hishikawa, Y., Warta, W. and Dunlop, E. D.. Prog. Photovolt: Res. Appl. 20, 12, 2010

Green, M. A., Emery, K., Hishikawa, Y., Warta, W. and Dunlop, E. D.. Prog. Photovolt: Res. Appl. 21, 827, 2013

Friedman, D. J.. Current Opinion in Solid State and Materials Science. 14, 131, 2010

Lavery, J.. M.S. Thesis, Naval Postgraduate School, Monterey, CA, 2008

Allen, C. R.. Ph. D. Thesis, Purdue University, West Lafayette, IN, 2010

Forouhi, A. R. and Bloomer, I. Phys. Rev. B 34, 7018, 1986

Adachi, S. Phys. Rev. B 39, 12612, 1989 